\title{
The Relation of Serum Vitamin D and Cathelicidin Levels in Recurrent Lower Respiratory Tract Infections in Preschool Children
}

\author{
Tekrarlayan Alt Solunum Yolu Enfeksiyonu Olan \\ Okul Öncesi Çocuklarda Serum Vitamin D ve Katelisidin Illişkisi
}

\author{
Esra Coşar', Tuğba Arıkoğlu², Asuman Akar³, Feryal Karahan4, Semanur Kuyucu², Necdet Kuyucu \\ 'Department of Pediatrics, Mersin University School of Medicine, Mersin, Turkey \\ 2 Department of Allergy and Immunology, Mersin University School of Medicine, Mersin, Turkey \\ ${ }^{3}$ Department of Pediatric Infectious Diseases, Mersin University School of Medicine, Mersin, Turkey \\ ${ }^{4}$ Department of Pediatric Hematology, Mersin University School of Medicine, Mersin, Turkey
}

\begin{abstract}
Objective: Lower respiratory tract infections (LRTIs) are common in preschool children. Recent evidence suggests that vitamin D (vit D) enhances the production of cathelicidin, which is highly expressed in respiratory epithelium. The aim of the study was to investigate the relation of serum vit $D$ and cathelicidin in preschool children with recurrent LRTIs.

Material and Methods: This prospective study included 56 preschool children under 5 years of age with LRTIs and 52 healthy controls. Complete blood count, serum 25(OH)D3, cathelicidin and C-reactive protein levels were measured in all children.

Results: The mean serum vit $D$ level of the children with recurrent LRTIs was $24.8 \pm 14.4 \mathrm{ng} / \mathrm{mL}$ and the healthy group was $25.1 \pm 10.7 \mathrm{ng} / \mathrm{mL}$ and no significant difference was found between groups $(p=0.922)$. Vit D deficiency was detected in 15 (13.9\%) of all the children participating in the study and vit D insufficiency in 30 (27.8\%) subjects. The median serum cathelicidin levels in children with recurrent LRTIs (39.6 ng/ $\mathrm{mL})$ were significantly lower than the healthy group $(77.8 \mathrm{ng} / \mathrm{mL})(\mathrm{p}=$ 0.004 ). No significant correlation was found between serum cathelicidin levels and vit $D$, white blood cell count, absolute neutrophil count and C-reactive protein. The serum cathelicidin levels $\leq 37.3 \mathrm{ng} / \mathrm{mL}$ were found to be related to the risk of recurrent LRTIs in preschool children independent of age, gender, body mass index and serum vit $D$ levels (OR: $0.99,95 \% \mathrm{Cl}$ : 0.98-0.99, $\mathrm{p}=0.006$ ).
\end{abstract}

Özet

Giriş: Okul öncesi çocuklarda tekrarlayan alt solunum yolu enfeksiyonları (ASYE) sık görülmektedir. Son zamanlardaki bilgiler göstermektedir ki; vitamin D (vit D), solunum yolu epitelinde eksprese olan katelisidin üretimini arttırmaktadır. Bu çalışmanın amacı okul öncesi tekrarlayan ASYE olan çocuklarda serum vit $D$ ve katelisidin ilişkisini araştırmaktır.

Gereç ve Yöntemler: Prospektif olan bu çalışmaya tekrarlayan ASYE'si olan 5 yaş altı 56 hasta ve 52 sağlıklı çocuk alınmıştır. Tam kan sayımı, serum $25(\mathrm{OH}) \mathrm{D} 3$, katelisidin ve C-reaktif protein düzeyleri tüm çocuklarda ölçülmüştür.

Bulgular: Tekrarlayan ASYE'si olan grubun ortalama serum vit $D$ düzeyi $24.8 \pm 14.4 \mathrm{ng} / \mathrm{mL}$ ve sağlıklı grubun ise $25.1 \pm 10.7 \mathrm{ng} / \mathrm{mL}$ olup gruplar arasında anlamlı bir fark saptanmadı $(\mathrm{p}=0.922)$. Çalışmaya katılan tüm çocukların 15 (\%13.9)'inde vit D eksikliği ve 30 (\%27.8)'unda vit D yetersizliği saptandı. Tekrarlayan ASYE'si olan grubun ortalama serum katelisidin düzeyi $(39.6 \mathrm{ng} / \mathrm{mL})$ ise sağlıklı gruptan $(77.8 \mathrm{ng} / \mathrm{mL})$ anlamlı olarak düşük saptandı $(p=0.004)$. Serum katelisidin düzeyleri ile vit $D$ düzeyi, beyaz küre sayısı, mutlak nötrofil sayısı ve C-reaktif protein düzeyleri arasında anlamlı bir korelasyon saptanmadı. Serum katelisidin düzeylerinin $\leq 37.3 \mathrm{ng} / \mathrm{mL}$ olmasının yaş, cinsiyet, vücut kitle indeksi ve serum vit $D$ düzeylerinden bağımsız olarak okul öncesi çocuklarda tekrarlayan ASYE ile ilişkili olduğu saptanmıştır (OR: 0.99, 95\% Güven aralığı: 0.98-0.99, $\mathrm{p}=0.006$ ). 
Conclusion: Lower cathelicidin levels were detected in children with recurrent LRTIs despite no significant difference in vit $D$ levels compared to healthy controls. This study suggests that lower cathelicidin levels may predispose to LRTIs or be used as a biomarker for recurrent LRTIs in preschool children.

Keywords: Lower respiratory tract infection, preschool children, vitamin D, cathelicidin

\section{Introduction}

Lower respiratory tract infections (LRTIs) are major causes of mortality in children under 5 years of age particularly in developing countries (1). Approximately two million children aged below five years die each year because of LRTIs (2). Identifying the risk factors and initiating the effective interventions are essential for management and prevention of LRTIs (3).

It has been shown that children with vitamin D (vit D) insufficiency or deficiency are more susceptible to respiratory infections (4-6). In recent years, the role of vit D in modulating the immune system has been the focus of interest. Vit D deficiency affects immune function by decreasing the host defenses against infections in children (7). Some previous studies indicated an association between vit $D$ levels and acute LRTIs in children $(6,8)$. Also, the ability of vit $D$ to enhance innate immunity through its role in inducing the production of antibacterial proteins such as cathelicidins is well documented (7).

Cathelicidin is a multifunctional host defense molecule that has several effects on the innate and adaptive immune systems that may be relevant in the modulation of infections. It has the potential to influence and modulate Toll-like receptor mediated responses and the activity of various cell populations involved in inflammatory processes $(9,10)$.

Vit $D$ deficiency and LRTIs are common health problems in preschool children in Turkey. There is a paucity of data investigating the relationship between recurrent LRTIs and serum vit $D$ and cathelicidin levels in this age group in our country and other countries and the results are conflicting $(11,12)$. The aim of the study was to investigate the relation of serum vit $D$ and cathelicidin in preschool children with recurrent LRTIs.

\section{Materials and Methods}

Children aged under 5 years of age who were admitted to the emergency department or department of Pediatric Infectious Diseases with a history of recurrent LRTIs and age and sex matched healthy controls between August 2016 - February 2017 were included in this prospective study. Recurrent LRTIs were defined as having bronchitis/bronchiolitis or pneumonia more than once in last six months or at least three episodes in the last one year $(13,14)$. Those children with prematurity,
Sonuç: Vit D düzeyleri açısından gruplar arasında anlamlı bir fark olmamasına rağmen tekrarlayan ASYE'si olan çocuklarda daha düşük katelisidin düzeyleri saptandı. Bu çalışma düşük katelisidin düzeylerinin tekrarlayan ASYE'ye yatkınlık yaratabileceğini veya okul öncesi çocuklarda tekrarlayan ASYE için bir biyobelirteç olarak kullanılabileceğini düşündürmektedir.

Anahtar Kelimeler: Alt solunum yolu enfeksiyonu, okul öncesi çocuklar, vitamin $\mathrm{D}$, katelisidin

low weight for gestational age, atopy, airway malformations, cardiac, neurological diseases, immunodeficiency, iron deficiency anemia, a history of second hand smoke, chronic respiratory diseases such as cystic fibrosis, ciliary dyskinesia and bronchopulmonary dysplasia and those who have a chronic disease or drug usage that can affect the levels of serum vit $D$ were excluded. In the healthy group, in addition to the aforementioned exclusion criteria, those who had upper respiratory tract infection in the last two weeks or had a history of recurrent LRTIs were also excluded.

Age, gender, height, weight and body mass index (BMI) of the study patients were recorded. BMI was calculated as weight in kilograms divided by the height in squared meters.

A serum 25-hydroxyvitamin $D$ level is considered to be the best circulating biomarker of vit $D$ status. Serum vit $D$ categorization was made as sufficient $(20-50 \mathrm{ng} / \mathrm{mL})$, insufficient $(12-20 \mathrm{ng} / \mathrm{mL})$, or deficient $(<12 \mathrm{ng} / \mathrm{mL})$ based on the previous recommendations (15).

Complete blood count, serum calcium, phosphorus, alkaline phosphatase and C-reactive protein levels were measured in all children. Serum 25-hydroxyvitamin D (Elecsys Vit D total, Roche Diagnostics Int. Ltd, USA) levels were analyzed by the Electro- chemiluminescence binding assay (ECLIA) method. Serum cathelicidin (human cathelicidin antimicrobial peptide (USCN Life Science Inc., Houston, Texas, USA) levels were measured by an enzyme-linked immunosorbent assay (ELISA) method. Blood samples were taken from cases with recurrent LRTIs during admission to the hospital for the LRTI episode and during the same week for each corresponding control.

The study was approved by the clinical research local ethics committee with the decision number 2016/290. All patients gave consent prior to taking part in the study.

\section{Statistical Analysis}

Statistical analyses were performed using the STATA/MP11 statistical software (StataCorp LLC, USA). Descriptive analyses were presented using median or mean \pm SD based on normal distribution or not. Unadjusted comparisons were made using the Independent samples t-test or Mann-Whitney $U$ test for continuous endpoints and the Chi-Square test for categorical endpoints. Correlations were assessed using the Spearman's 
correlation test. A multivariate logistic regression model was used to identify independent predictors of recurrent LRTIs. Odds ratios with their $95 \%$ confidence intervals were estimated. Roc curve analysis was performed to determine the cut-off value for recurent LRTIs. A p value of less than 0.05 was considered statistically significant.

\section{Results}

A total of 108 preschool children (56 patients with recurrent LRTIs and 52 healthy controls) were enrolled. The mean age was $34.2 \pm 14.8$ months in the group with recurrent LRTIs and $34.1 \pm 14.7$ months in healthy controls. Twenty-two (39.3\%) of the patient group and $28(53.8 \%)$ of the healthy group were female. No significant differences were found between the two groups in terms of age $(p=0.913)$, gender $(p=0.129)$ and BMI $(p=0.696)$ (Table 1).

The mean serum vit $D$ level of the children with recurrent LRTIs was $24.8 \pm 14.4 \mathrm{ng} / \mathrm{mL}$ and the healthy group was $25.1 \pm$ $10.7 \mathrm{ng} / \mathrm{mL}$ and no significant difference was found between groups ( $p=0.922$ ) (Table 1$)$. Vit $D$ deficiency $(<12 \mathrm{ng} / \mathrm{mL}$ ) was detected in 15 (13.9\%) (9 in the group with LRTIs and 6 in healthy controls) of all the children participating in the study. Vit D insufficiency $(12-20 \mathrm{ng} / \mathrm{mL})$ was found in $30(27.8 \%)(15$ in the group with LRTIs and 15 in healthy controls) of all subjects. No significant differences were found between groups according to vit $D$ categories. There were no significant differences between groups in terms of serum calcium, phosphorus and alkaline phosphatase levels. The median serum cathelicidin level was 39.6 ( $\min : 0.6$, max: 200.7 ) $\mathrm{ng} / \mathrm{mL}$ in children with recurrent LRTIs and 77.8 (min: 0.6 , max: 208.4$) \mathrm{ng} / \mathrm{mL}$ in the healthy group and the cathelicidin levels were found to be significantly lower in children with LRTIs $(p=0.004)$ (Table 1$)$.

No significant correlation was found between serum cathelicidin levels and vit $D(p=0.450)$, white blood cell count ( $p=$ $0.964)$, absolute neutrophil count $(p=0.950)$ and C-reactive protein levels $(p=0.687)$. There was a significant positive correlation between serum cathelicidin levels and BMI (spearman correlation coefficient rs: $0.267, p=0.047$ )(data not shown).

In order to identify the independent predictors of recurrent LRTIs, logistic regression analysis was used. The serum cathelicidin levels were found to be significantly related to the risk of recurrent LRTIs in preschool children independent of age, gender, BMI and serum vit D level (aOR: $0.99,95 \%$ Confidence Interval: 0.98-0.99, $\mathrm{p}=0.006$ ) (Table 2).

In the Roc curve analysis, serum cathelicidin levels $\leq 37.3$ $\mathrm{ng} / \mathrm{mL}$ were found to be significantly related to the risk of recurrent LRTIs (AUC: $0.654, p=0.004$, sensitivity: $50 \%$, specificity: $81 \%$, positive predictive value (PPV): $74 \%$ and negative predictive value (NPV): 60\%) (Figure 1).

\section{Discussion}

Lower respiratory tract infections represent an important public health problem leading to high mortality and morbidity rates in preschool children (16). Vit $D$ deficiency has been shown to be associated with increased risk of infectious diseases $(6,8)$. The determination of a preventable risk factor such as vit $D$ deficiency and initiation of the effective intervention is quite important in the management of LRTIs in children.

Table 1. The comparison of demographic characteristics, serum vitamin D, cathelicidin levels and biochemical parameters between study groups

\begin{tabular}{|c|c|c|c|}
\hline Variable & $\begin{array}{l}\text { Children with LRTIs } \\
\qquad \mathrm{n}=56\end{array}$ & $\begin{array}{l}\text { Healthy controls } \\
\qquad n=52\end{array}$ & $\mathbf{p}$ \\
\hline Age (months) & $34.2 \pm 14.8$ & $34.1 \pm 14.7$ & 0.913 \\
\hline Female gender n(\%) & $22(39.3)$ & $28(53.8)$ & 0.129 \\
\hline Weight (kg) & $13.7 \pm 3.2$ & $14.2 \pm 2.9$ & 0.387 \\
\hline BMI $\left(\mathrm{kg} / \mathrm{m}^{2}\right)$ & $16.2 \pm 1.9$ & $16.4 \pm 1.9$ & 0.696 \\
\hline Serum calcium (mg/dL) & $9.8 \pm 0.7$ & $10.2 \pm 0.7$ & 0.106 \\
\hline Serum phosphorus (mg/dL) & $5.0 \pm 0.7$ & $5.3 \pm 1.3$ & 0.216 \\
\hline Alkaline phosphatase (U/L) & $190.5 \pm 53.4$ & $96.9 \pm 47.9$ & 0.520 \\
\hline Serum vitamin $D(\mathrm{ng} / \mathrm{mL})$ & $24.8 \pm 14.4$ & $25.1 \pm 10.7$ & 0.922 \\
\hline $\begin{array}{l}\text { Vitamin D deficiency n (\%) } \\
\text { Vitamin D insufficieny n (\%) }\end{array}$ & $\begin{array}{c}9(16.1) \\
15(26.8)\end{array}$ & $\begin{array}{c}6(11.5) \\
15(28.8)\end{array}$ & 0.833 \\
\hline Serum cathelicidin* (ng/mL) & $39.6(0.6-200.7)$ & $77.8(0.6-208.4)$ & 0.004 \\
\hline
\end{tabular}


Table 2. Logistic regression analysis of factors that are related to recurrent lower respiratory tract

\begin{tabular}{|l|c|c|}
\hline Variable & Odds ratio (95\% Cl) & p \\
\hline Age $($ months) & $0.98(0.95-1.01)$ & 0.290 \\
\hline Male gender & $2.08(0.89-4.83)$ & 0.087 \\
\hline BMl $\left(\mathrm{kg} / \mathrm{m}^{2}\right)$ & $0.91(0.72-1.13)$ & 0.397 \\
\hline Serum vitamin D $(\mathrm{ng} / \mathrm{mL})$ & $1.82(0.34-9.70)$ & 0.483 \\
\hline Serum cathelicidin $(\mathrm{ng} / \mathrm{mL})$ & $0.990(0.984-0.997)$ & $\mathbf{0 . 0 0 6}$ \\
\hline BMl: Body mass index. & & \\
\hline
\end{tabular}

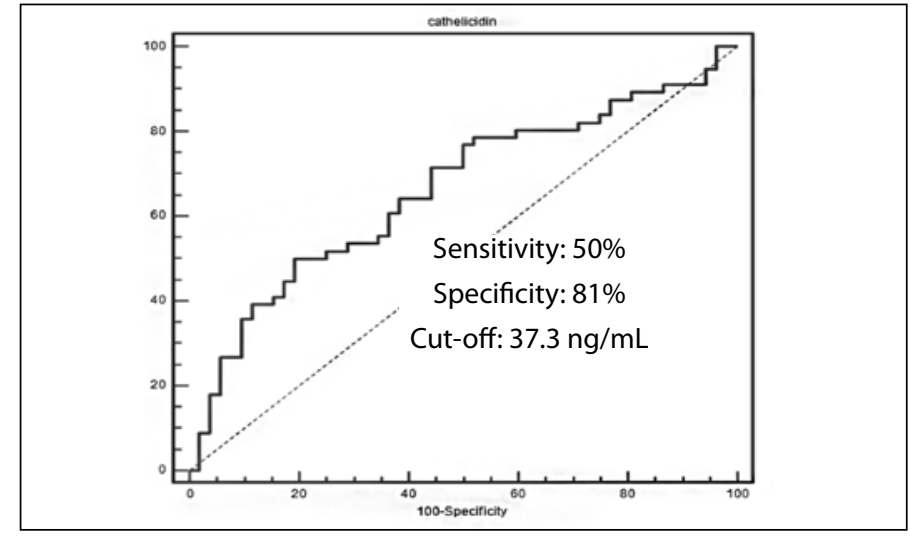

Figure 1. The receiver operating characteristic curve (Roc) analysis for serum cathelicidin to predict the risk of recurrent LRTIs (AUC: 0.654, $p=0.004$, sensitivity: $50 \%$, specificity: $81 \%$ ).

In our country, vit D deficiency and LRTIs are common health problems in preschool children (17). The discovery that most tissues and cells in the body have a vit $D$ receptor and the ability to convert the primary circulating form of vit $D$ to the active form has provided new insights into the function of this vitamin (18). Vit $D$ is not just a hormone also has an important role in cellular and humoral immunity and pulmonary functions $(4,5,7)$. Previous studies have reported that vit $D$ deficiency has a negative impact on the prevalence of LRTIs and disease severity and increases intensive care and oxygen requirements of patients with LRTIs $(6,8)$. However, observational studies evaluating the relationship between serum $25(\mathrm{OH}) \mathrm{D}$ concentrations and respiratory infections have had conflicting results. While some previous studies found significant correlation between increased numbers of respiratory tract infections and significantly lower mean $25(\mathrm{OH}) \mathrm{D}$ levels, others showed no significant difference in vit $D$ levels between patients with respiratory tract infections and controls $(6,8,19-21)$. In the present study, $41.7 \%(45 / 108)$ of the all subjects had either vit $D$ deficiency or insufficiency. Although no significant difference was found in terms of vit $D$ levels between our study groups, the levels of vit $D$ were lower than normal in approximately half of the children with recurrent
LRTIs (42.8\%). Consistent with our results, McNally et al found no difference in vit $D$ levels between the subjects with acute LRTIs and control groups. However, they reported that significantly more children admitted to the pediatric intensive care unit with acute LRTI were vit $D$ deficient. They suggested that the immunomodulatory properties of vit $D$ might influence acute LRTI disease severity (20).

Cathelicidin is a part of the innate immune response and has extensive antimicrobial and immunomodulatory effects such as chemoattractant function, inhibition of neutrophil apoptosis, tissue regeneration and cytokine release (22-24). In a previous study with 112 adults hospitalized with community-acquired pneumonia, values of serum cathelicidin in the lowest tertile (overall median $69 \mathrm{ng} / \mathrm{mL}$, range 13-263) were associated with a higher 30-day mortality (25). In another case-control study among individuals initiating chronic hemodialysis $(n=$ 279), patients with serum cathelicidin levels in the lowest tertile had an increased rate of death due to infection over 1 year (26). They also showed that cathelicidin was strongly associated with white blood cell count. A single-center study of 82 children with bronchiolitis reported an inverse association between serum cathelicidin levels and severity of illnes. They reported that serum $25(\mathrm{OH}) \mathrm{D}$ levels were not correlated with cathelicidin levels in the setting of acute infection, but that cathelicidin was associated with viral etiology (12). Consistent with the previous studies we also showed that the serum cathelicidin levels $\leq 37.3$ $\mathrm{ng} / \mathrm{mL}$ were found to be significantly related to the risk of recurrent LRTIs in preschool children independent of age, gender, $\mathrm{BMI}$ and serum vitamin D level $(12,27)$. We could not find a significant relation between cathelicidin and infection parameters such as white blood cell count, absolute neutrophil count and $C$-reactive protein.

Vit $D$ has been shown to upregulate the expression of cathelicidin in respiratory epithelial cells and plays a major role in host defense (28). However, no association was found between serum vit $D$ and cathelicidin levels in the present study. Consistent with our results, Leow et al demonstrated that 25-hydroxyvitamin D levels were not correlated with se- 
rum cathelicidin in adult patients with community acquired pneumonia (25). On the other hand, Quraishi and colleagues demonstrated in a randomized placebo-controlled trial in 30 patients with sepsis that supplementation with high-dose cholecalciferol increased circulating levels of $25(\mathrm{OH}) \mathrm{D}$, bioavailable $25(\mathrm{OH}) \mathrm{D}$, and cathelicidin. However, they only found a positive correlation between bioavailable $25(\mathrm{OH}) \mathrm{D}$ and cathelicidin (29).

The factors other than vit $D$ are also known to play a role in determining the cathelicidin levels. Regulatory small molecules that act as co-activators and co-repressors and the endoplasmic reticulum stress signaling pathway independent of vit $D$ receptor play a role in the determination of cathelicidin levels (30). Although we could not find a significant difference in vit $D$ levels between the study groups, lower cathelicidin levels were detected in children with LRTIs. Thus, one may think that lower cathelicidin levels independently related to recurrent LRTIs in preschool children.

In the present study, a positive correlation was found between serum cathelicidin levels and BMI. In our previous study with asthmatic children, there was a significant positive correlation between $\mathrm{BMI}$ and serum levels of cathelicidin (31). Benachour et al. showed that cathelicidin messenger RNA expression was significantly positively correlated with BMI (32). The effects of adipose tissue on cathelicidin gen regulation (messenger RNA expression) is unclear. However, it can be thought that the proinflammatory cytokines secreted from adipose tissue, e.g., leptin, may induce the cathelicidin production $(33,34)$.

We acknowledge some potential limitations. First, there is a relatively small sample size. Second, our data were based on serum vit $D$ and cathelicidin levels which may not reflect the status in the lung. However, our findings will shed on light into understanding the relation between vit $\mathrm{D}$, cathelicidin and LRTls in preschool children.

In conclusion, lower cathelicidin levels were detected in children with recurrent LRTIs despite no significant difference in vit D levels compared to healthy controls. The present study suggests that lower cathelicidin levels may predispose to LRTIs or be used as a biomarker for recurrent LRTIs in preschool children. Further studies with cathelicidin as a potential treatment for LRTIs are required.

Ethics Committe Approval: The study was approved by the clinical research local ethics committee.

Informed Consent: Patient consent was received prior to taking part in the study.

Peer-review: Externally peer-reviewed.

Author Contributions: Concept - NK; Design - EC; Supervision - TA, SK, NK; Data Collection and/or Processing - EC, AA, FK; Analysis and/ or Interpretation - EC, TA, NK; Literature Review - EC, AA, FK; Writing TA, SK; Critical Review - SK, NK.

Conflict of Interest: The authors have not reported a conflict of interest.

Financial Disclosure: There is no financial support in this study.

\section{References}

1. Pettifor JM. Vitamin D and its role in the management and prevention of lower respiratory tract infections in infants and young children. Indian Pediatr 2016;53:965-66.

2. The World Health Report 2005: Redesigning child care: Survival, growth and development. Geneva: World Health Organization, 2005;127-43.

3. Schaad UB, Principi N. The management of recurrent respiratory tract infections in children. Europ Infect Dis 2012;6:111-5.

4. Larkin A, Lassetter J. Vitamin D deficiency and acute lower respiratory infections in children younger than 5 years: identification and treatment. J Pediatr Health Care 2014;28:572-82.

5. Velarde Lopez AA, Gerber JS, Leonard MB, Xie D, Schinnar R, Strom $B L$. Children with lower respiratory tract infections and serum 25-hydroxyvitamin D3 levels: A case-control study. Pediatr Pulmonol 2016:51:1080-7.

6. Mansbach JM, Piedra PA, Borregaard N, et al. Serum cathelicidin level is associated with viral etiology and severity of bronchiolitis. J Allergy Clin Immunol 2012;130:1007-8.e1.

7. Hewison M. Vitamin D and immune function: an overview. Proc Nutr Soc 2012;71:50-61.

8. Roth DE, Shah R, Black RE, Baqui AH. Vitamin D status and acute lower respiratory infection in early childhood in Sylhet, Bangladesh. Acta Paediatr 2010;99:389-93.

9. Agier J, Efenberger M, Brzezińska-Błaszczyk E. Cathelicidin impact on inflammatory cells. Cent Eur J Immunol 2015;40:225-35.

10. Kahlenberg JM, Kaplan MJ. Little peptide, big effects: the role of LL-37 in inflammation and autoimmune disease. J Immunol 2013;191:4895901.

11. Hasegawa K, Mansbach JM, Ajami NJ, et al. Serum cathelicidin, nasopharyngeal microbiota, and disease severity among infants hospitalized with bronchiolitis. J Allergy Clin Immunol 2017;139:13831386.e6.

12. Mansbach JM, Piedra PA, Borregaard N, et al. Serum cathelicidin level is associated with viral etiology and severity of bronchiolitis. J Allergy Clin Immunol 2012;130:1007-8.e1.

13. Schaad UB, Esposito S, Razi CH. Diagnosis and management of recurrent respiratory tract infections in children: a practical guide. Arch Pediatr Infect Dis 2016;4:e31039.

14. Study Group of the Italian Society of Pediatric Immunology. Recurrent infection in children: definition and diagnostic approach. Rev Immunol Allergy Pediatr 1988;2:127-34.

15. Munns CF, Shaw N, Kiely M, et al. Global Consensus Recommendations on Prevention and Management of Nutritional Rickets. JClin Endocrinol Metab 2016;101:394-415.

16. Bryce J, Boschi-Pinto C, Shibuya K, Black RE; WHO Child Health Epidemiology Reference Group. WHO estimates of the causes of death in children. Lancet 2005;365:1147-52.

17. Şişmanlar T, Aslan AT, Gülbahar Ö, Özkan S. The effect of vitamin $D$ on lower respiratory tract infections in children. Turk Pediatri Ars 2016:51:94-9. 
18. Holick MF. Vitamin D deficiency. N Engl J Med 2007;357:266-81.

19. Karatekin G, Kaya A, Salihoğlu O, Balci H, Nuhoğlu A. Association of subclinical vitamin $D$ deficiency in newborns with acute lower respiratory infection and their mothers. Eur J Clin Nutr 2009;63:473-7.

20. McNally JD, Leis K, Matheson LA, Karuananyake C, Sankaran K, Rosenberg $A M$. Vitamin $D$ deficiency in young children with severe acute lower respiratory infection. Pediatr Pulmonol 2009;44:981-8.

21. Roth $D E$, Jones $A B$, Prosser $C$, Robinson JL, Vohra S. Vitamin D status is not associated with the risk of hospitalization for acute bronchiolitis in early childhood. Eur J Clin Nutr 2009;63:297-99.

22. Harcourt JL, McDonald M, Svoboda P, Pohl J, Tatti K, Haynes LM. Human cathelicidin, $L L-37$, inhibits respiratory syncytial virus infection in polarized airway epithelial cells. BMC Res Notes 2016;9:11.

23. Bucki R, Leszczyńska K, Namiot A, Sokołowski W. Cathelicidin LL-37: a multitask antimicrobial peptide. Arch Immunol Ther Exp (Warsz) 2010;58:15-25.

24. Andersson DI, Hughes D, Kubicek-Sutherland JZ. Mechanisms and consequences of bacterial resistance to antimicrobial peptides. Drug Resist Updat 2016;26:43-57.

25. Leow $L$, Simpson $T$, Cursons $R$, Karalus $N$, Hancox RJ. Vitamin $D$, innate immunity and outcomes in community acquired pneumonia. Respirology 2011;16:611-6.

26. Gombart AF, Bhan I, Borregaard N, et al. Low plasma level of cathelicidin antimicrobial peptide (hCAP18) predicts increased infectious disease mortality in patients undergoing hemodialysis. Clin Infect Dis 2009;48:418-24.
27. Mansbach JM, Hasegawa K, Ajami NJ, et al. Serum LL-37 Levels Associated With Severity of Bronchiolitis and Viral Etiology. Clin Infect Dis 2017;65:967-75.

28. Hansdottir S, Monick MM, Hinde SL, Lovan N, Look DC, Hunninghake GW. Respiratory epithelial cells convert inactive vitamin $D$ to its active form: potential effects on host defense. J Immunol 2008; 181:7090-9.

29. Quraishi SA, De Pascale G, Needleman JS, et al. Effect of Cholecalciferol Supplementation on Vitamin D Status and Cathelicidin Levels in Sepsis: A Randomized, Placebo-Controlled Trial. Crit Care Med 2015;43:192837.

30. Park K, Elias $P M$, Oda $Y$, et al. Regulation of cathelicidin antimicrobial peptide expression by an endoplasmic reticulum (ER) stress signaling, vitamin Dreceptor-independent pathway. J Biol Chem 2011;286:3412130.

31. Arikoglu T, Kuyucu S, Karaismailoglu E, Batmaz SB, Balci S. The association of vitamin $D$, cathelicidin, and vitamin $D$ binding protein with acute asthma attacks in children. Allergy Asthma Proc 2015;36:518.

32. Benachour H, Zaiou M, Samara A, et al. Association of human cathelicidin (hCAP-18/LL-37) gene expression with cardiovascular disease risk factors. Nutr Metab Cardiovasc Dis 2009;19:720-8.

33. Schäffler A, Schölmerich J. Innate immunity and adipose tissue biology. Trends Immunol 2010;31:228-35.

34. Zhang $L$, Guerrero-Juarez CF, Hata $T$, et al. Innateimmunity. Dermal adipocytes protect against invasive Staphylococcus aureus skin infection. Science 2015;347:67-71. 